MUZIKOLOŠKI ZBORNIK - MUSICOLOGICAL ANNUAL XV, LJUBLJANA 1979

UDK $681.816 .61(497.13=863)$

\title{
ORGULJE SLOVENSKIH GRADITELJA U HRVATSKOJ1
}

\author{
Ladislav $\check{\mathrm{S}}$ a b a n (Zagreb)
}

Najraniji poznati podatak koji se odnosi na orgulje, a koji ukazuje na neke veze između Hrvatske i Slovenije potječe iz 1501. godine, kada je 20. novembra zagrebački kapitol odredio da orguljaš katedrale Jeronim pođe u Maribor i dovede odanle Mateja »organistu «ạ da popravi orgulje. Za putni trošak je Jeronimu odobrio 3 florena. ${ }^{2}$ Odmah početkom iduće godine Matej je došao u Zagreb i uoči blagdana sv. Priske (17. januara) sklopio pogodbu da će za 92 florena izvršiti popravak, kojom mu je prilikom plaćen 1 floren za putni trošak i 1 floren kao predujam. ${ }^{3} \mathrm{U}$ jesen u blagdanu sv. Leonarda (20. XI) iste godine Mateju je u ime pogodbe i plaće isplaćeno samo 25 florena, ${ }^{3 a}$ čime je jamačno prekinut posao jer nema daljih upisa da je još što primio. Može biti da su orgulje postradale u strašnom potresu koji je zadesio Zagreb 25 . marta iste 1502. godine i skoro ga razorio. Jer 1505. i 1506. radi jedan drugi orguljar, majstor Marko, za kora se nabavljaju velike količine kositra za pravljanje svirala i zlato za pozlatu kućišta. što ukazuje na mogućnost da su se tada gradile nove orgulje. ${ }^{4}$

O Matejevoj struci nemamo posve jasnu sliku zahvaljujući dvoznačnosti kojega u to vrijeme ima naziv »organista «. Mogao je biti gradski orguljaš župne crkve u Mariboru koji je znao popravljati, pa i graditi, orgulje (takvih je više poznato u Hrvatskoj iz istog ili kasnijeg stoljeća), ali on je mogao biti i neki putujući graditelj orgulja, vjerojatno Nijemac, koji je baš u to vrijeme u Mariboru gradio ili popravljao orgulje, što je također vrijedan podatak. Iz tih se razloga ne može sa

1. Ovaj rad je skraćena verzija istoimenog većeg rada.

$1 a$ U latinskim tekstovima 16. stoljeća, dakako i ranije, riječ o r g a $\mathrm{n}$ i s t a u to vrijeme može biti dvoznačna. Po prvotnom značenju ona označuje čovjeka koji orgulje s v i r a (organist, orguljaš u užem smislu), pa drugotnom pak značenju to je čovjek koji orgulje g r a d i (orguljar, graditelj orgulja). Najkasnije u 17. stoljeću slijedi točno razgraničenje pojmova na određeni djelokrug: »organista« je samo čovjek koji svira orgulje, a graditelj je »organifex«, «Confector organi (organarum)« ili »magister organi (organarum)«. Prema tome prije 17. stoljeća treba riječ »organista « tumačiti individualno, od slučaja do slučaja.

2 I. K. Tkalčić. Povijesni spomenici slob. kralj. grada Zagreba (dalje SPOMENICI), XI, Zagreb 1905, str. 298.

3 Ibidem, str. 303 i 304.

3a Ibid., str. 304.

4 Tkalčić, SPOMENICI, III (1896), str. 7, kao i rukopisni još neobjavljeni sveščić računa katedrale iz 1506. god. u Nadbiskupskom arhivu (dalje NA), Acta oeconomica aedificalia, vol. 494, ann. 1510-1805. 
sigurnošću tvrditi da je Matej jedan od najranijih poznatih slovenskih graditelja orgulja koji je u Mariboru imao radionicu, jer takvih orguljara u to još vrijeme nema, zbog malog broja orgulja oni su prisiljeni putovati za poslom od grada do grada, često u nevjerojatno udaljene krajeve. Mogućnost da je Matej takav putujući graditelj koji se slučajno bavio u Mariboru, objašnjavala bi çinjenicu zašto 1505. orgulje u Zagrebu ne gradi on, nego drugi.

U Sloveniji se najranije poznate stalne orguljarske radionice javljaju u 17. stoljeću, ponajprije u Ljubljani, a u 18. stoljeću u Celju i nešto kasnije u Mariboru. Ta tri središta nisu u pogledu orguljarstva podjednako značajna, a nije im ni životni vijek bio jednak. Najjači je centar svakako Ljubljana, gdje se orgulje grade u kontinuitetu od 17. stoljeća do danas. U Celju se grade orgulje samo u 18. stoljeću, dok su tamo radili Ivan Franjo Janeček i Anton Scholz, dok se u Mariboru značajnije radionice javljaju tek oko druge polovine 18. stoljeća i traju zaključno do 1938. uz više velikih prekida u 19. stoljeću.

Sva su tri navedena centra bila od velike važnosti po Hrvatsku jer su se iz njih dobavljale brojne orgulje, od kojih je još priličan broj sačuvan. Kratak osvrt na rad orguljara iz tih centara, koliko njihova djela stoje u vezi s Hrvatskom, a i na rad nekih orguljara iz manjih pokrajinskih mjesta, biti ce predmet ovoga prikaza.

\section{LJUBLJANSKI KRUG}

Najraniji u Hrvatskoj poznati ljubljanski graditelj orgulja, ujedno i najzanimljiviji, bio je IVAN FALLER.

O njegovoj se biografiji jedva što zna, što je velika šteta jer se radi o značajnom baroknom graditelju. Pošto se on na zagrebačkom dokumentu iz 1688. potpisuje kao »Burger und Orgel Macher in Laibach,$^{5}$ znak je da je već prije te godine stekao građansko pravo u Ljubljani, što upućuje na to da je već dulje vremena ondje živio i radio. Za sada nisu poznate ni potpune godine njegova života a ne zna se niti odakle je došao i gdje je izučio struku. Jedino pomoću analize dispozicije njegovih orgulja u Zagrebu može se stvoriti zaključak o pripadnosti njegova umijeća jednom određenom graditeljskom krugu, o čemu nešto kasnije.

Faller je u Lagrebu radio dva puta: najprije nove orgulje za crkvu sv. Katarine isusovačkog kolegija (1688-89), ${ }^{6}$ a godinu dana kasnije radio je na pregradnji i obnovi orgulja katedrale $(1689-90) .^{7} \mathrm{Za}$ isusovačke je orgulje poznato samo toliko da su imale jedan manual, 15 registara ( 12 u manualu, 3 u pedalu) i 4 mijeha. Katedralne su orgulje takoder imale samo jedan manual, ali zato 19 registara (16 u manualu, 3 u pedalu) te dodatne »registre « ptičice (aviculas), dvostruku

5 Vidi niže navedene dokumente.

6 Originalni ugovor u Arhivu Hrvatske (dalje AH), Acta collegii S.J. Zagrabiensis irregestrata, fasc. VIII/10(). U istoj su skupini takuđer sačuvane namire o isplatama tih orgulja pod sign. VII/194, 202 i 220.

7 NA, Acta Capituli antiqua, fasc. 101/57. Također je sačuvana jedna namira priložena spisima pod istim brojem. 
kukavicu (cucu duplex) i tremulant (?). ${ }^{8}$ Prerađujući i povećavajući starije orgulje, koje je 1647. gradio orguljaš iste katedrale i graditelj orgulja Gregor Štrukel (+1650), ${ }^{9}$ Faller je imao zadržati 6 starih registara (ne kaže se u tekstu koje), popraviti ih ako treba, a sve ostale registre izraditi posve nove kao i nove zračnice (cistas pro ventis permittendis) te obnoviti kanale (canales) i mjehove (folles).

Posrednim putem uspjelo je utvrditi za ocjenu orgulja vrlo važnu činjenicu, da je temeljni registar principal tih velikih orgulja počivao na veličini od samo 8 stopa, ${ }^{10}$ što je opet omogućilo identificiranje veličine ostalih registara. Tako je dobiven vrlo karakterističan i neobičan pregled sastava dispozicije, kojega radi karakterističnosti ovdje iznosimo (nazivi registara ostavljeni su kao u originalu, veličine su naknadne i zato stavljene u zagradu):

Ma n u a l:

1. Principale (8)

2. Principalis octava (4) VIII

3. Principalis quinta $(22 / 3)$

4. Octava (2) XV

5. Quinta (1 $1 / 3)$ XIX

6. Supra octava (1) XXII

7. Supra quinta $(2 / 3) X X V I$

8. Octavula $(1 / 2)$ XXIX

9. Quintula $(1 / 3)$ XXXII

10. Mixtura quadruplex (2)

11. Tertia $(13 / 5)$

12. Cymbalum (1)

13. Copula (8)

14. Fistula tecta seu fletta (4)

15. Sylvestris fistula seu fletta (4)

16. Cuspidata chori fistula (2 ili 4 )

$8 \mathrm{U}$ citiranom se ugovoru spominje »novam balbeturam [elaboret] «. U meni dostupnim rječnicima nisam mogao pronaći riječ »balbetura «, pa pomišljam da se radi o slučajno nastaloj izvedenici iz glagola »balbetire«, što bi značilo mucati, zamuckivati, pa bi riječ balbetura tada značila »mucalo, zamuckivalo «, što bi se povezano s instrumentom moglo prevesti kao »mucalo na orguljama «, a to bi se jedino moglo odnositi na tzv. tremulant, dakle na napravu kojom se uzrokuje podrhtavanje, tremoliranje, »mucanje« glasova.

9 J. Barlè, Orgulje u Zagrebu i njegovoj okolici prije sto godina. SV. CECILIJA, Zagreb 1910 (IV), str. 3. - Gregor Štrukel je vrlo zanimljiva ličnost, možda također porijeklom iz Slovenije ili Štajerske. U Zagrebu se prvi put javlja 1621, kada vrši popravak orgulja katedrale; otprilike 1628. god. preuzima ispražnjeno mjesto katedralnog organiste-orguljaša, 1634. povećava tamošnje orgulje za 5 registara i gradi za toranj katedrale rog (Hornwerk), a 1647. i čitave orgulje koje su imale 13 registara, koje je Faller povećavao.

$10 \mathrm{Za}$ orgulje katedrale taj je podatak izveden prema jednom kasnijem ugovoru o popravku orgulja, načinjenom s neimenovanim graditeljem orgulja 1721. god. (isti arhiv, pod istim brojem kojim i Fallerov ugovor), koji je imao nanovo izraditi sve Fallerove svirale (dodao je samo Salicional), a u pedalu zamijeniti jedan od tri registara pozaunom, zbog čega je uz svaki pojedini registar stavljena točna naznaka njegove veličine. Kod toga je značajno da se tu izričito spominje da temeljni principal (od 8 stopa) u prospektu mora ostati o $\mathrm{n} \mathrm{a} \mathrm{j}$ s t a r i tj. Fallerov, možda čak još Strukelov. 
P e d a l:

17 Portuna octava (16)

18. Portuna (8)

19. Portuna fletta (4?)

U toj je dispoziciji posebno karakteristična snažna koncentracija registara na jednom jedinom manualu (ovdje 16, kod isusovačkih orgulja 12), zatim velika i razgranato stupnjevana skupina principalovih registara (br. 1-12), u kojoj postoji očita srodnost $\mathrm{s}$ r i p i e n o m u talijanskim orguljama (ti su registri radi veće preglednosti označeni rimskim brojkama), uz obogaćenje s dubokom kvintom prema njemačkom običaju (Talijani tu kvintu u ripienu ne grade), zatim uz dodatak tada još dosta rijetkog alikvotnog registra Terca (Talijani ga također ne grade, ${ }^{11}$ kao i dvjema njemačkim miksturama (četverostruka i Cimbel). Također iz Njemačke vuku porijeklo i ostala 4 manualna registra (br. 13-16), koji zvukovno kontrastiraju skupini principala i mogli bi, kao skupina kako su ovdje poredani, stajati u zasebnom manualu, da je postojao drugi manual. To su dvije poklopljenice (br. 13 i 14), zatim Silvestra ili bolje poznata kao Waldflöte 4, te konična polupoklopljenica Cuspidata ili poznata kao Spitzflöte, po svoj prilici 4-stopne veličine. Vrlo je karakteristično, a to ćemo i kod kasnijih graditelja susretati, da Faller ne voli graditi jezičnjake - nije ih bilo po svoj prilici ni u isusovačkim orguljama - a pozaunu u pedalu koja je postojala u Štrukelovim orguljama (i koja je opet vraćena 1721) zamijenio je flautnim registrom.

Prema toj se zanimljivoj dispoziciji, kojoj u literaturi nije lako naći srodnih a kamoli istovetnih, se sigurnošću može zaključiti da se tu očituju u okvirima odrednica svojstvenih južno-njemačkoj školi i izraziti utjecaji iz talijanskog graditeljstva (ripieno!), što opet ukazuje na moguća središta u kojima je Faller u mladosti učio gradnju orgulja. Talijanski se utjecaji mogu naći u Tirolu i južnoj Bavarskoj (kamo po svoj prilici spada Faller), ali i u pojedinim radionicama u Salzburgu, Passau-u i Ceškoj. ${ }^{12}$

Dodajmo na kraju još zanimljivu opasku, da su se iz Slovenije, točnije iz Ljubljane i Kamnika u Hrvatsku dovozile orgulje sve do sredine 19. stoljeća rijekom Savom, kako se u ugovorima izričito spominje. Kraj tadašnjeg stanja cesta, taj sigurno »najmekaniji « ali zato opasniji put ponukao bi naručitelje da u ugovorima uvijek naznače da transport rijekom do odredišta ide na isključiv rizik $\mathrm{i}$ trošak graditelja.

Kao slijedeći graditelj nakon Ivana Fallera javlja se iz Ljubljane ANDRIJA SEBASTIJAN WALLENSTEIN, koji je 27. septembra 1708. sklopio ugovor s franjevcima na Kaptolu u Zagrebu za gradnju jednih orgulja od 12 registara. Te

11 Prema Mahrenholzu, registar Terz javlja se u renesansi najprije u Francuskoj, odakle u baroku prelazi u jużnu (!) Njemačku, a tek u IY. stoljeću i u sjevernu, gdje postaje vrlo karakterističan registar u njemačkim orguljama - Usp. Chr. Mahrenholz. Die Orgelregister, ihre Geschichte und ihr Klang, Kassel 1968 (II izd.), str. 207-8.

$12 \mathrm{O}$ graditeljima koji su gradili pod utjecajima iz Italije usp. O.Eberstaller, Orgeln und Orgelbauer in Oesterreich, Graz-Köln 1956. - R. Quoika, Die altösterreichische Orgel der späten Gotik, der Renaissance und des Barock, Kassel 1953. - Isti, Der Orgelbau in Böhmen und Mähren, Mainz 1966. 


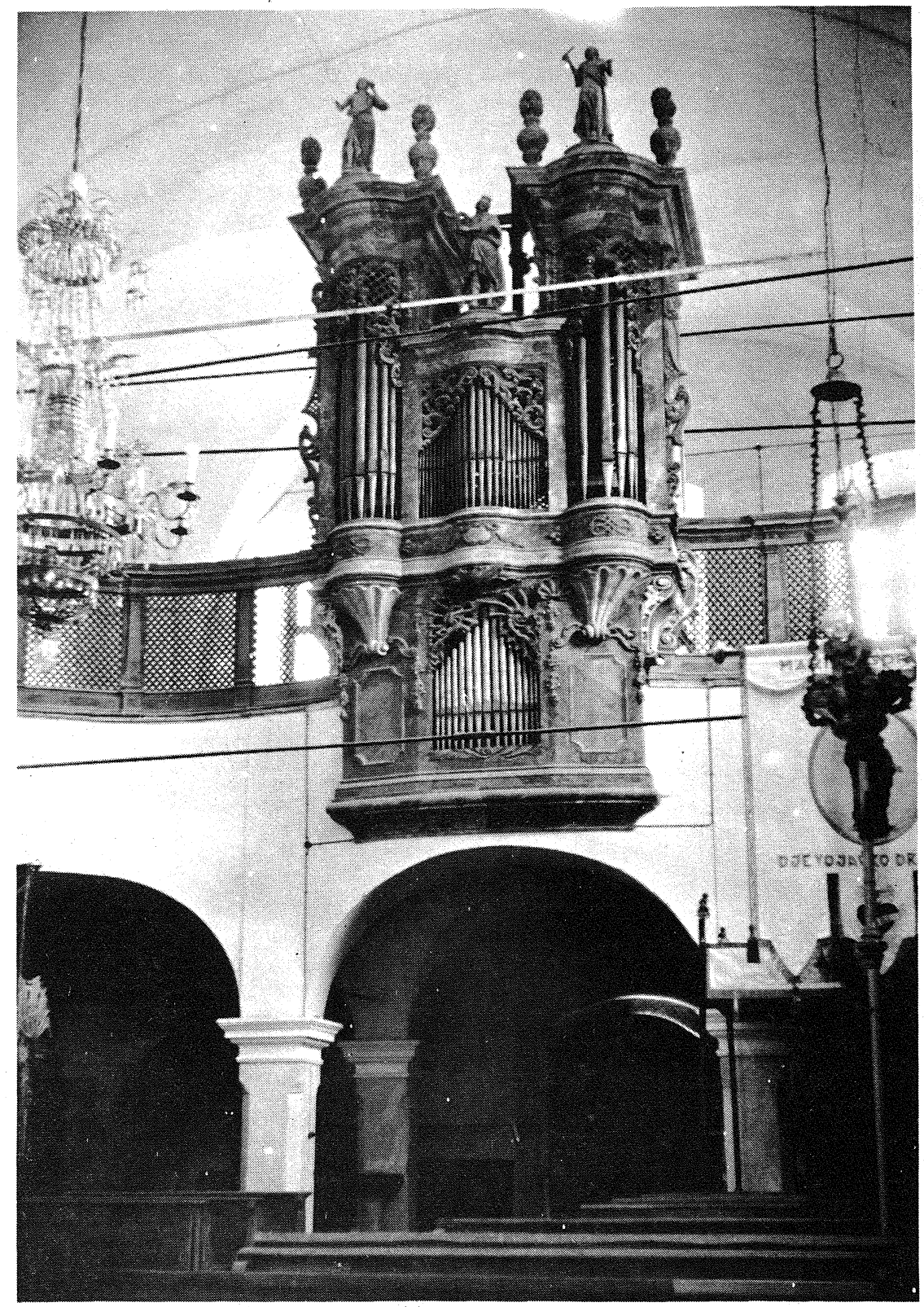

Sl. 1 Marija Gorica (I. J. Eisl, 1759) 
orgulje on ipak nije uspio dovršiti jer je u toku gradnje umro u Zagrebu, vjerojatno sredinom $1709 \mathrm{i}$ bio sahranjen u samostanskoj kripti. ${ }^{13}$

Pošto se na ugovoru potpisao kao »izrađivač orgulja u Ljubljani« (Orgelmacher zu Leybach), a ne kao »građanski graditelj orgulja (Burgerlicher Orgelmacher), zaključujemo da nije bio građanin nego samo stanovnik Ljubljane. ${ }^{14}$

Ne znamo kod kojega su majstora u Ljubljani isusovci iz Slavonske Požege naručili jedan pozitiv, ali se zna da je 1706. bio dopremljen rijekom Savom u Slavoniju. ${ }^{15}$ Takvih je narudžbi iz Slavonije tijekom 18. stoljeća bilo vjerojatno i više, jer tada počinju tamošnje crkve opremati orguljama.

Dosta smo upućeni o životu i radu IVANA JURJA EISLA (oko 1708-1780), opet jednom važnijem ljubljanskom graditelju. Znamo da je rođen u Salzburgu ili

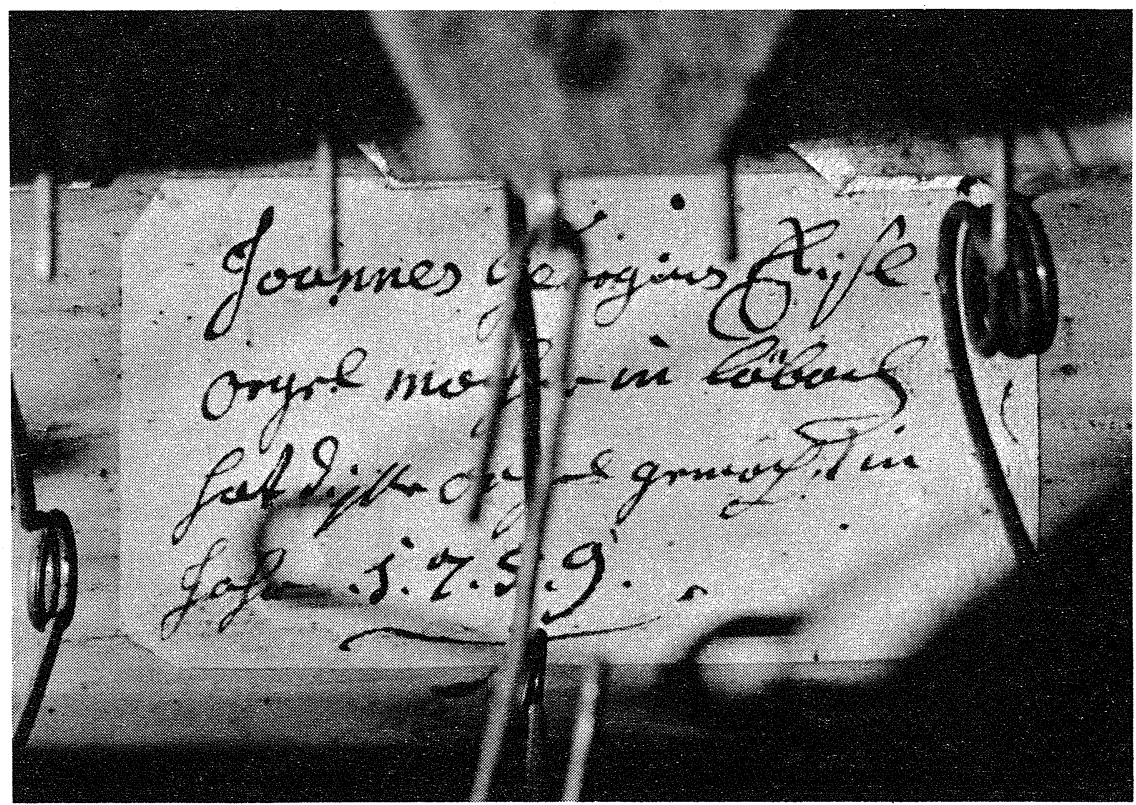

S1. 2 Marija Gorica, Eislov zapis u orguljama

13 NA, Acta Capit. ant., fasc. 101/68 i 69. Oba su spisa u osnovi identična, ali u spisu br. 69 ima dosta naknadnih unesaka, tako podatak o dispoziciji orgulja, materijalu kojega treba nabaviti, kao i o smrti graditeljevoj.

14 J. Barlè, Nešto o starim franjevačkim orguljama u Zagrebu. SV. CECILIJA 1914 (VIII), str. 81.

15 J. Barlè, Nešto o crkvenoj glazbi kod požeških isusovaca. SV. CECILIJA 1912 (VI), str. $79-80$. 
u salzburškom okružju (»von Salzburg gebihrtig«), ${ }^{16}$ gdje je vjerojatno izučio svoj zanat, po svoj prilici u radionici poznatog graditelja Joh. Chr. Egedachera (16641747). ${ }^{17}$ Premda Eisl živi u Ljubljani još od 1741. godine, građanstvo je stekao tek 21. februara $1763 .{ }^{18}$ Zato je razumljivo zašto se u zapisima u svojim orguljama kao i na poznatim dokumentima pisanim prije 1763. uvijek potpisuje samo kao »Orgel macher in Läbach» (sl. 1 i 2).

U Hrvatskoj su sačuvane njegove orgulje, od kojih se po svojim krasnim kućištima posebno ističu one u Mariji Gorici (1759) i u Sv. Petru u Šumi u Istri (oko 1770).

Karakteristično je za Eislov način gradnje da izbjegava kvintne registre, uz Principal 8 uvodi i talijanski tremulant zvan VOX HUMANA, da od kontrastnih registara osim obih poklopljenica (8 i 4) gradi još samo otvorenu flautu 4, a nikada jezičnjake. Kod dvomanualnih orgulja on nikada ne izdvaja pozitiv kao zasebno tijelo ispred orgulja (Rückpositiv), nego ga smještava u bazu kućišta, a sviraonik uvijek ugrađuje u začelje orgulja u plitku nišu. ${ }^{19}$

JOSIP ALOJZ KUČERA gradio je samo jedne orgulje koje postoje u Hrvatskoj (Lipnik, 1785) i vršio više popravaka u Karlovcu i njegovoj okolini. Prema pronađenoj cedulji u orguljama u Lipniku one su bile njegovo deseto djelo, a potpisao se kao ljubljanski građanin i graditelj orgulja. ${ }^{20}$ Neke sličnosti u načinu gradnje dopuštaju pretpostavku da je Kučera možda radio u Eislovoj radionici. Izgleda da ga nije dostigao.

S Kučerom završava krug starijih graditelja iz Ljubljane koji su radili za Hrvatsku a bili su pripadnici baroka. Graditelji koje pola stoljeća kasnije susrećemo biti će pripadnici smjera koji se u orguljarstvu naziva romantizmom. Karakteristike tog novog smjera jesu: 8-stopni registri zastupani su u većem broju nego ranije, čime se u zvuku orgulja pojačava dominacija osnovnih registara; uz principiale i već poznate poklopljenice obavezno se susreću registri imitatori gudača (Gamba 8, Viola 4, u pedalu Violonbass); od ostalih kontrastnih registara u pravilu su prisutni Salicional ili Gemshorn ili oba zajedno; u principalovoj skupini nestaju registri viši od Superoctava 2, obično postoji samo dublja kvinta, a čitava skupina završava pretežno $s$ dvostrukom miksturom (ponekad s dvostrukom i trostrukom,

16 L. Šaban, Orgulje ljubljanskog graditelja orgulja Ivana Jurja Eisla u Hrvatskoj. ARTI MUSICES, I, Zagreb 1969, str. 116.

17 Što sve u Eislovu načinu rada upućuje na Egedacherovu radionicu, objasnio sam u gore spomenutom radu.

18 Šaban, o.c, str. 116.

19 Ostali radovi o Eislu: O. Eberstaller, Die Orgeln..., str. 104 i 176. - L. Šaban, The Organs of Ivan Juraj Eisl in Croatia, THE ORGAN YEARBOOK, Amsterdam 1972, vol. III, str. 41-52. - Isti, Kako su gradili orgulje $i$ crkvu u Mariji Gorici $i$ štošta oko toga. Revija KAJ, Zagreb 1977, br. 3-4, str. 24-40). - Isti, Bilješke o orguljama, orguljašima $i$ glazbenicima u jastrebarskom kraju. Revija KAJ, Zagreb 1975, br. 1-3, str. 184. - Isti, Povijest orgulja pavlinskog samostana u Sveticama. Revija KAJ, Zagreb 1977, br. 9-10, str. 63-74. - J. Mantuani pogrešno pripisuje Križmanu Eislove orgulje u franj. samostanu u Novom Mestu (1764).

20 U orguljama pronađena izvorna cedulja glasi: "Nro. 10, zu Ehre Gottes fecit Joseph Aloisi Kutschera Burgl. Orgel Macher in Laybach, den 14 May 1785«. - Dokumentacija o orguljama u arhivu republičkog zavoda za zaštitu spomenika kulture u Zagrebu (RZZSK); također zapisnik evidencije br. 30 od 12. VII 1974. 
dakle s dvjema), koje su bez oštrine. Te orgulje imadu ugodnu zvukovnu punoću, imadu i boja, ali im manjka sjaj.

Tri ljubljanska orguljara koji se najprije javljaju imadu mnogo zajedničkoga u načinu gradnje, što se ne može previđeti, po čemu bi se moglo zaključivati na neki zajednički izvor njihova umijeća. Ti graditelji su ANDREJ FERDINAND MALACHOVSKY (181221_1887), FRAN GORŠIČ (1836-1898) i FRANC KSAVER DEV (1837-1872). Samo je prvi po porijeklu stranac (Čeh), dok se za Goršiča zna da je učio kod Carla Hessea. ${ }^{22}$ No baš to što se u orguljama Malachovskoga po prvi put nakon Eisla opet susreće talijanski tremulant VOX HUMANA, koju gradi i Hesse, a s druge strane, opet, postoje mnoge i frapantne sličnosti s načinom gradnje Goršiča, Hesseova učenika, a konačno $i$ istovetnost karaktera zvuka orgulja Malachovskog i Goršiča, sve to navodi na pomisao da i Malachovskoga po svoj prilici treba dovesti u vezu s Hesseom bilo za njegova boravka u Trstu ili kasnije u Beču. Do koje se mjere, opet, može i Deva dovesti u vezu sa gornjom dvojicom i Hesseom, zá sada mi nije poznato. Činjenica je da njegove orgulje u Gerovu u potpunosti nalikuju Malachovskijevima u Plešcima. ${ }^{23}$.

Orgulje sve trojice graditelja ${ }^{24}$ ostavljaju utisak dobre zanatske vještine dobro izobraženih orguljara, čiji rad valja poštivati.

Ljubljanski krug zatvaraju dva moderna graditelja: IVAN MILAVEC (18741915) i FRANC JENKO (1895-1968). Malobrojna Milavčeva djela u Hrvatskoj ne pokazuju više one visoke vrednote i domete koje je prema iskazima suvremenika Milavec kao značajan graditelj postizavao. Povijesno je značajno da je on, uz braću Zupan i Brandla, bio među prvima od slovenskih graditelja koji je primjenjivao pneumatski sustav.

21 G. Radole (L'arte organaria in Istria, Bologna, str. 60-61) navodi 1812. kao godinu rođenja, dok St. Premrl (Nekolike statistike o orglah v ljubljanski škofiji, CRKVENI GLASBENIK, Ljubljana 1918) navodi godinu 1813.

22 CARL HESSE, rođen u Baruthu (Berlin), otvorio je iza 1835. god. vlastitu radionicu najprije u Trstu, a oko 1850. u Beču, gdje se uskoro pročuo i mnogo gradio za Austriju, Mađarsku i Hrvatsku. Dok je bio u Trstu upoznao se temeljito s mletačkom klasičnom gradnjom orgulja (Nakić-Callido), od koje je mnoge tekovine preuzeo i nastojao ih spojiti s njemačkim načinom gradnje. Među takvim su osebinama klasični talijanski ripieno i VOX HUMANA (principalov tremulant). - Usp. O. Eberstaller, o.c., str. 143-144; G. Radole, o.c., str. 137.

${ }^{23}$ Također nije još objašnjeno do koje se mjere i kojim načinom može povezati Malachovskoga s Janezom Mandlinom; Mandlinove orgulje u Čabru (1864), iako na śviraoniku piše njegovo ime, mogle bi se bez daljnjega pripisati Malachovskomu, na kojega kao autora (da li zabunom?) upućuje i jedna bilješka u ZAGREBAČKOM KATOLIČKOM LISTU, 1864 , br. 2 , str. 14.

24 Podaci u RZZSK.

24a U SV. CECILIJI i drugim crkvenim glasilima ima poveći broj prikaza Jenkovih orgulja u Hrvatskoj. Najvažniji su napisi koji se odnose na orgulje u Đakovu: F. Dugan, Nove orgulje u Đakovu, SV. CECILIJA 1937 (XXXI), br. 1, str. 7-9. - Dr. Z. M., Kolaudacija novih orgulja, GLASNIK BISKUPIJE BOSANSKE I SRIJEMSKE, Đakovo 1936 (XLIV), str. 169-171. U istom broju na str. 171-174 slijedi objavljeno predavanje Frana Kimovca, održano u povodu kolaudacije orgulja, pod naslovom »Nove orgulje u Đakovačkoj katedra$l i \ll$, koji napis sadrži objašnjenje u vezi raznih stručnih pitanja. - Podaci o evidenciji i ostala dokumentacija, RZZSK. 
Daleko se više od Milavca u Hrvatskoj afirmirao FRANC JENKO, osobito kada je 1936. sagradio orgulje u katedrali u Đakovu ( 73 registara). ${ }^{24 a}$ Tako veliko djelo nije imao sreće graditi nijedan od jugoslovenskih graditelja osim Jenka. Otada je dobivao u Hrvatskoj brojne narudžbe za nove orgulje ili je vršio mnoge pregradnje starijih orgulja. Nakon njegove smrti tvrtka je ipak nastavila s radom. Danas u Hrvatskoj postoji 25 orgulja tvrtke Jenko. ${ }^{25}$

\section{CELJSKI KRUG}

Nakon Ljubljane Celje se javlja već u trećem deceniju 18. stoljeća kao orguljarski centar koji je bio od velikog značenja po Hrvatsku, ponajviše zahvaljujući dvojici vrijednih graditelja koji su tamo djelovali: IVANU FRANJI JANEČEKU (oko 1698- iza 1777) ${ }^{26}$ i ANTONU SCHOLZU (+1800?).

Otac Ivana Franje Janečeka, Martin »Janezig«, doselio je u Celje iz Češke vjerojatno poč. 18. stoljeća, a umro je prije $1721 .^{27}$ Po svoj prilici i on je bio graditelj. Ivan Franjo rodio se jamačno krajem 17. stoljeća, jer je 1722. primio u Celju građanstvo, ${ }^{28}$ za što mu je osim određenog imutka bila u najmanju ruku potrebna i punoljetnost, koja se u ono vrijeme češće priznavala tek s 24 . godinom. God. 1721 oženio se u Celju s Marijom kćerkom krojača Adama, s kojom je imao dvoje djece, ${ }^{29}$ kojom se prilikom njegov otac spominje kao već pokojan. Prema datumima gradnje njegovih orgulja u Hrvatskoj (1726-1777), Janeček je doživio duboku starost u krepkom zdravlju, do kraja gradeći orgulje.

U Hrvatskoj se Janečckovo ime po prvi put spominje 1726, koje je godine za 315 florena gradio jedan manji pozitiv za katedralu u Zagrebu. ${ }^{30}$ No vrlo je vjerojatno da je upravo Janeček onaj majstor koji je 1721. obnavljao Fallerove orgulje, čije se ime u tada sastavljenom ugovoru ne spominje. Janeček je od početka bio u Hrvatskoj vrlo cijenjen i uživao je znatnu podršku crkvenih dostojanstvenika u kaptolu. Posebno se istakao kada je 1740. dobio narudžbu uglednog kanonikakantora Jurja Reesa (oko 1670-1745), koji je u njega naručio velike orgulje sa 22

25 Podaci u RZZSK.

26 Obiteljsko ime glasi J a n e č e k, nipošto Janaček ili Janiček. Treba odmah upozoriti na jednu krupnu pogriješku: majstor se Janeček čitava života služi tiskanom ceduljom na kojoj je njegovo prezime (krivo pročitano) tiskano kao G e n e c h e k, ‘u kojem se obliku inače nigdje drugdje ne susreće. No u 18. stoljeću općenito ljudi još nisu bili jako osjetljivi na ispravnost pisanja vlastitog prezimena kao ni na ortografiju, što vrijedi i za Janečeka. Da je oblik J a n e č e k jedina ispravna varijanta v. R. Quoika, Der Orgelbau in Böhmen... str. 101.

27 Biografske podatke o Janečeku sabrao je Barlè, Orgulje župske crkve u Brezovici, SV. CECILIJA 1937 (XXXI), str. 89-90). - Isti, Još o celjskom graditelju orgulja Ivanu Janačeku, SV. CECILIJA, 1937 (XXXI), str. 148. - Barlè Janečeka pogrešno naziva Janaček!

28 W. Suppan, Steirmärkisches Musiklexikon, Graz 1962-66, str. 260.

29 Barle, o.c.

30 Barlè, Joś nešto... str. 89. 


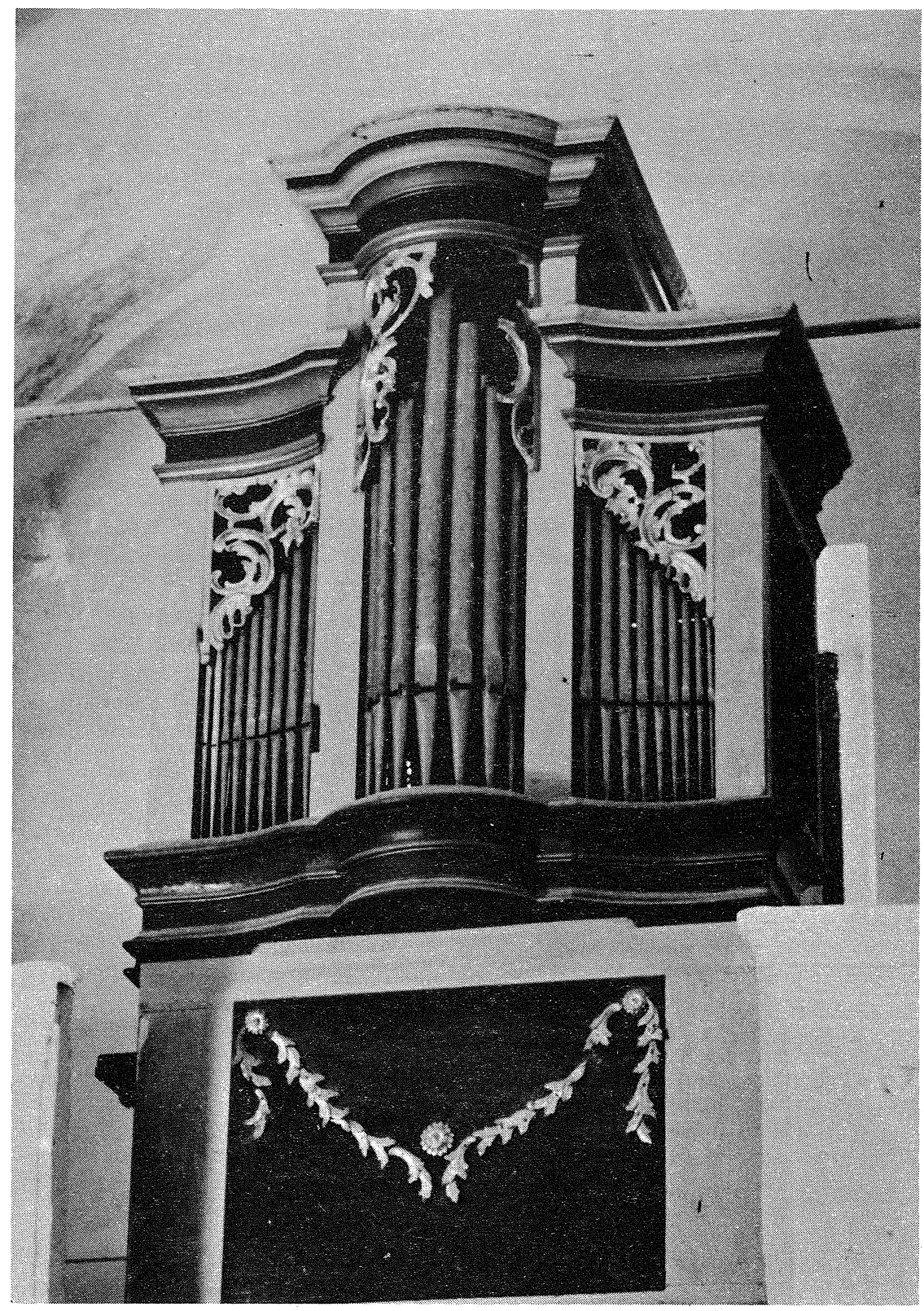

Sl. 3 Kupinec (I.F. Janeček, 1752) 
registra kao svoj dar crkvi sv. Marka svog rodnog grada Zagreba. ${ }^{31} \mathrm{Te}$ su orgulje bile tada najveće u Hrvatskoj, a samo za jedan registar manje od onih koje je Janeček 1732. gradio u stolnoj crkvi u Ljubljani, što sve zagrebačkim orguljama daje posebnu povijesnu dimenziju. Te su orgulje maknute 1884., a da nije o njima zabilježen ni najmanji podatak, pa ni njihova dispozicija, što je neoprostiv propust.

Janeček je najviše gradio za crkve pod protektoratom kaptolske gospode (Sisak, Sela kraj Siska), za župe u okolici Zagreba (Brdovec, Kupinec /sl. 3/, Brezovica) ili za pavlinski samostan u Lepoglavi odnosno za njegov novicijat koji je bio smješten na pavlinskom posjedu u Olimju kod Podčetrtka u Štajerskoj. ${ }^{32}$ Danas je u Hrvatskoj sačuvano samo 4 Janečekovih instrumenata. ${ }^{33}$

Janeček je gradio posvema u duhu češke graditeljske škole, čiji je izdanak, što se može dokazati i uspoređivanjem dispozicija s orguljama koje postoje u Češkoj. Dispozicija orgulja sv. Marka u Zagrebu bila je po svoj prilici jednaka dispoziciji orgulja katedrale u Ljubljani, koja je poznata; ${ }^{34}$ te su orgulje imale dva manuala, ali pozitiv nije bio izdvojen iz korpusa orgulja. Ta je dispozicija srodna orguljama Abrahama Starka (1659-1709) u Zlatoj Koruni (1698) ili još više orguljama Joh. Ign. Schmieda (1727-1802) u Březnu (1759) u Češkoj. ${ }^{35}$ Dispozicija Janečekovih orgulja u Olimju u potpunosti odgovara dispoziciji orgulja Wenzela Starka (1670-1757) u Mostima (1737-41). ${ }^{35 a}$ Konačno, dispozicija Janečekovih pozitiva također odgovara češko-austrijskoj školi.

Te je srodnosti trebalo naglasiti kako bi se ukazalo na nepravdu koju je Križman učinio Janečeku u poznatoj njegovoj ocjeni ljubljanskih orgulja, jer velik broj Križmanovih prigovora ide ustvari na račun opreka dviju posve različitih graditeljskih pravaca (Križman gradi na talijanski način, zagovara ga i hvali, Janeček pak na češki, kojega Križman indirektno osporava), a tek se manji dio prigovora proteže na Janečekovu zanatsku vještinu, iako i tu dosta tendenciozno. ${ }^{36}$

31 O Jurju Reesu kao darovatelju orgulja sv. Marka v. J.Barlè, Povijest župa i crkava zagrebačkih, I, Župa sy. Marka, Zagreb 1896, str. 17. - O Janečeku kao autoru tih orgulja, što se sve do nedavna nije znalo v. bilješku u računima gradskog magistrata u Zagrebu za g. 1742, koja glasi: »Die 29 Augusti (1742) in domo Praetorea ex cassa Civitatis ex quietantiam organificis, pro novo organo dati sunt eidem o r g a $\mathrm{n}$ i f i c i C i l e n s i (a to može biti samo Janeček, op. L.Š.) flor. Rhen. quinquaginta «, što je bio valjda samo jedan od dodatnih manjih izdataka, pošto je Rees platio instrument, bojadisanje i pozlatju. (Hist. arhiv u Zagrebu, Protocollum introitus et exitus Civitatis Zagrabiensis annorum 1699-1754, bez pag., pod odnosnom godinom).

32 Lični obilazak 1970. i 1979.

33 Podaci o tim instrumentima u RZZSK, zap. evid. br. 141 i 178 iz 1974. i br. 159 iz 1973. Osim pozitiva u Laduču i orgulja u Olimju svi su ostali Janečekovi instrumenti danas posve zapušteni, neki čak oštećeni (Sela) i nesposobni za sviranje. Ipak, restauracija je kod svih moguća; pozitiv u Brezovici upravo se rekonstruira pomoću kopija svirala Janečekova pozitiva u Laduču, koji posao vrši tvrtka Heferer.

34 R. Quoika, Die altösterreichische Orgel... str. 49 - J. Mantuani ne donosi čitavu dispoziciju.

35 R. Quoika, Der Orgelbau in Böhmen..., str. 109 i 114.

35 a Ibidem, str. 113.

36 O Križmanovim spisima v. J.Mantuani, Frančišek Ksaver Križman izdelovalec orgelj, SV. CECILIJA 1927, str. 84-86, 118-122. Treba primijetiti da Mantuanijev način analiziranja Križmanova djela, posebno pak interpretiranje Križmanovih spisa danas više ne zadovoljava jer ne odgovara stanju nauke i zato bi trebalo cijeli materijal ponovo temeljito proučiti. 




Sl. 4 Dvorac Bistra (A. Scholz, oko 1784) 
Uprkos Križmanova omalovažavanja, koje sigurno nije doprlo do nas, Janeček je za našu sredinu neosporno vrlo važan: on je u svoje vrijeme bio jedan od najboljih graditelja koji su u 18. stoljeću tu radili (Križmana treba izostaviti iz razmatranja jer se on ionako samo prolazno i kratkotrajno zadržavao u domovini), on na naše tle kao prvi presađuje način gradnje iz svoje domovine Češke, kojom on ustvari još podržava baroknu tradiciju koja je i prije njega tu postojala, iako sada u novom, zapravo prijelaznom obliku. S novim registrima on unosi izvjesne zvukovne promjene, iako još u dosta skromnoj mjeri. Janeček radi zanatski vrlo savjesno i pomno odabire kvalitetan materijal, zbog čega su njegove orgulje izdržljive i imaju veliku trajnost, što će omogućivati njihovo restauriranje. Konačno, nije nevažno da je i zvukovna strana njegovih instrumenata suvremenicima vrlo odgovarala, koji ju uvijek pohvalno spominju. Za volju objektivnije ocjene vrijednosti Janečeka nasuprot Križmanu trebalo bi poći srednjim putem relativnog vrednovanja, a ne putem izravne konfrontacije dviju u svemu nemjerljivih ličnosti.

ANTON SCHOLZ gradi pozitive koji su po konstrukciji i sastavu napadno nalik Janečekovima, pa ga u pomanjkanju bilo kakvih biografskih podataka moramo povezati s Janečekovom radionicom, koju je vjerojatno nastavio.

Gradio je mnogo za Hrvatsku, gdje se sačuvalo 8 njegovih pozitiva i orgulja, većina njih još dobro očuvanih i sposobnih za upotrebu. Pleno tih pozitiva uvijek je plemenito zvučan, raskošan, pun neke vedrine i sjaja. Jedine njegove sačuvane orgulje (Kostajnica, 1797) na žalost su zapuštene pa im se ne zna zvukovna vrijednost. Izvrstan i lak izgovor njegovih instrumenata čini ih vrlo podesnima za izvođenje stare glazbe. Posebno treba istaknuti ljepotu izrade nekih od kućišta s finim rokoko rezbarijama, bogatom pozlatom (dvorac Bistra, sl. 4) i kvalitetnim skulpturama svirajućih anđela (Dol). Po ljepoti opreme tih nekoliko Scholzovih instrumenata ide u red likovno najaktivnijih primjeraka iz tog vremena u Hrvatskoj; kao instrumenti pak idu u red najvrijednijih koji su sačuvani.

\section{MARIBORSKI KRUG}

U 18. stoljeću postojala su u Mariboru dva graditelja orgulja, predstavnika baroknog stila, koji su mnogo radili za znatan dio krajeva sjeverne Hrvatske. To su Simon i Josip Otonič, za koje pretpostavljamo da su otac i sin.

O biografiji SIMONA OTONIČA ${ }^{37}$ zna se samo toliko, da se 1760 . u Grazu oženio kćerkom tamošnjeg poznatog graditelja orgulja češkog porijekla Antuna Roemera (1724-1774); u to je vrijeme još bio pomoćnik. ${ }^{38}$ Uz sve to ničim nije dokazano da je bio i Roemerov učenik, iako postoji neka vjerojatnost i za to.

Čini se da Simon 1766. još nije bio stekao građanstvo u Mariboru, jer se u pozitivu u Sopotu (sl. 5) potpisao samo kao »pravitelj orgulja«. Već u slijedećem nama poznatom pozitivu (Radovan, 1774, sl. 6), kao i u svim kasnijim instrumen-

37 Simon se nije nikada služio takvim oblikom prezimena već samo njemačkim (Ottonischer, Odtonischer, Ottonitscher, Odonitzer i sl.). Josip, naprotiv, svoje prezime uvijek piše kao Otonič (Ottonitsch, Odonitsch), što će valjda biti pravi oblik obiteljskog imena, kojega slijedim i ja.

38 H. Federhofer, Beiträge zur Geschichte des Orgelbaues in der Steiermark. AUS ARCHIV UND CHRONIK, Graz 1951 (IV), sv. 1, str. 46. 


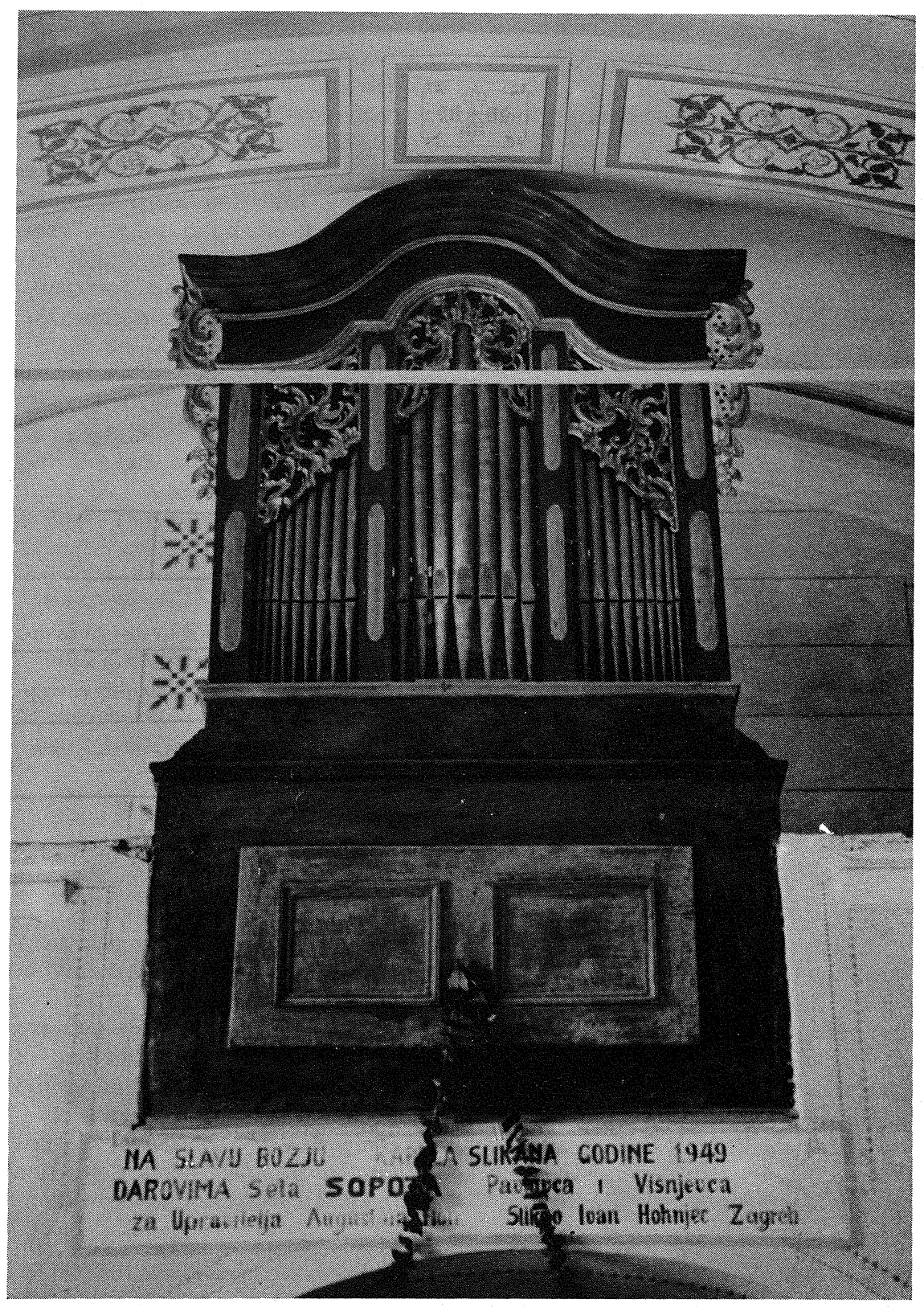

Sl. 5 Sopot (S. Otonič, 1766) 


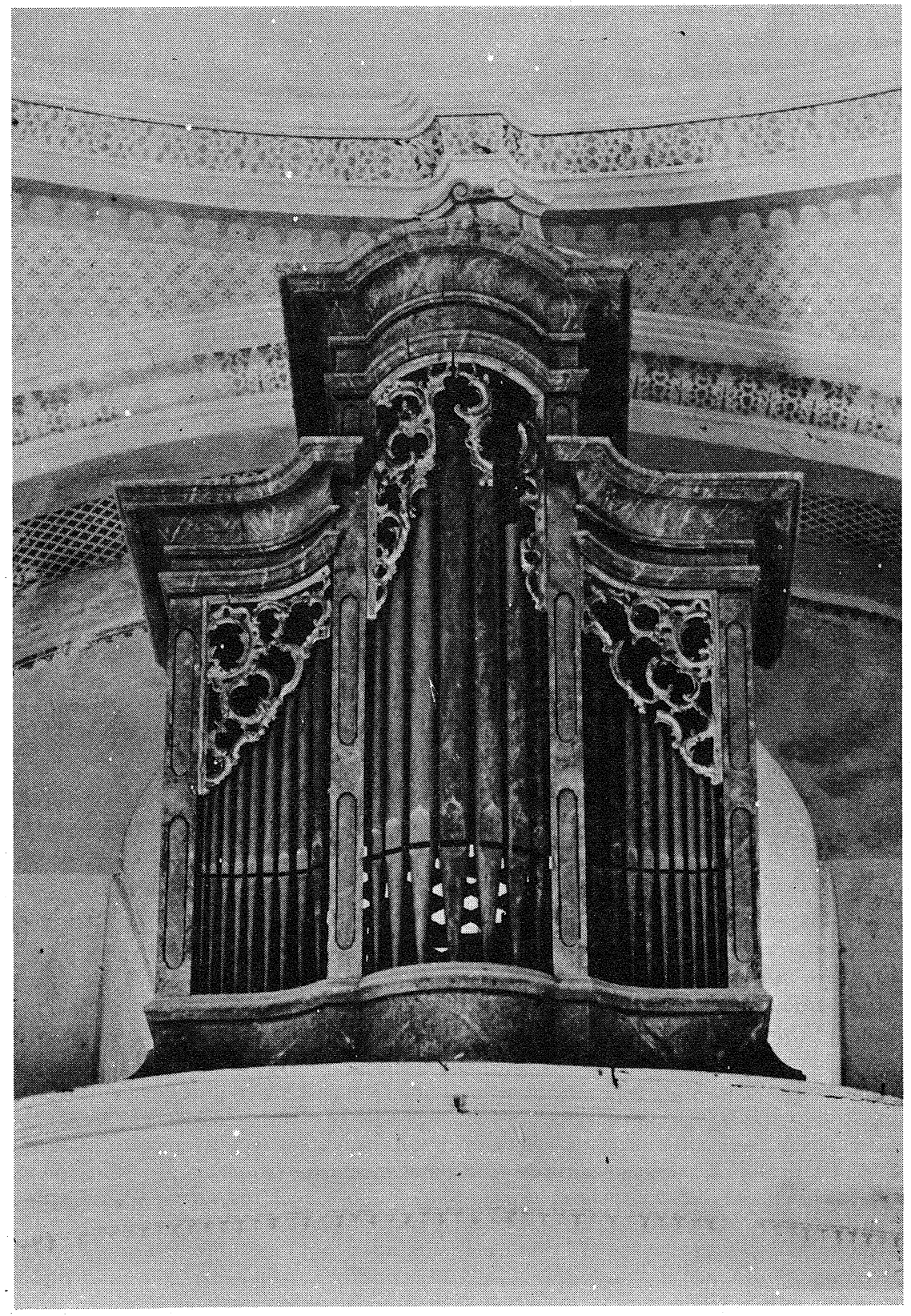

Sl. 6 Radovan (S. Otonič, 1774) 
tima redovito se potpisuje kao »Građanski pravitelj orgulja«, što je znak da je stekao građanstvo.

JOSIP OTONIČ najranije se javlja 1788. godine, kada se upisao u očev pozitiv u Zelendvoru prilikom nekog popravka. ${ }^{39}$ Zadnji trag njegovoj djelatnosti potječe iz 1817 , koje je godine popravljao orgulje u Kotoribi u Međimurju. ${ }^{40}$ Umro je tijekom 1817. ili početkom 1818. godine, ostavivši iza sebe ženu i troje nezbrinute djece is mnoštvom nepodmirenih dugova. ${ }^{41}$ Tragove njegovoj djelatnosti susrećemo nizvodno uz Dravu do Koprivnice, te na potezu od sjevernog Međimurja do Kutine u Posavini na jugu.

Naslijediv po svoj prilici dobro uvedenu radionicu svoga oca, Josip je u početku razvio iznenađujuće pozitivnu poslovnu djelatnost i dolazio do brojnih narudžbi kao jedva koji od starijih slovenskih graditelja. Prema rednim brojevima produkcije, koje je običavao stavljati u svoje instrumente, može se zaključiti da je izradio najmanje pedesetak orgulja, što je vrlo mnogo za ono vrijeme kada se sve ručno izrađivalo.$^{42} \mathrm{Da}$ je ipak tako naglo propao, krivnja leži ponajviše na ratnim prilikama toga nadasve nemirnog razdoblja, kada su svi njegovi pomoćnici morali na bojište, radionica ostala bez radne snage pa nije više bio u stanju udovoljavati preuzetim obavezama. Da bude nevolja veća, on je za sve obećane poslove uzimao predujmove koje odjednom nije bio u stanju vratiti pa su ga mnogi gonili putem okružnih vlasti, što se sve saznaje iz zapisa u Spomenici župe Gornja Rijeka.

Konstrukcija kućišta obojice Otoniča je istovetna: kod pozitiva sviraonik je uvijek ugrađen u začelnoj strani instrumenta, smješten neposredno na zračnicu, dok su mjehovi uvijek u bazi instrumenta i aktiviraju se povlačenjem remenja. Naprotiv, svoje orgulje grade po štajerskom regionalnom stilu: sviraonik se uvijek nalazi na bočnoj strani kućišta u plitkoj niši, dok su povlačnice registara (manubriji) poredane visoko gore iznad stalka za note i u jednom redu, a povlačnice pedalnih registara s lijeve strane svirača nešto niže dolje. ${ }^{42 a}$

Dispozicije njihovih orgulja još su barokne: pozitivi pokazuju uobičajenu shemu toga vremena, dok kod orgulja ima i nekih posebnih crta; najinteresantnije je da kod manjih orgulja ne grade pedalni registar Subbass 16, nego se zadovoljavaju s $8+4$, zbog čega se osjeća da orguljama nedostaje temelj u plenu, jer se pedalni

39 (Olovkom): »Joseph Odonitsch Orgel und Instrument Macher in Mahrburg 1788 Reparirt «, što ujedno kazuje da u to vrijeme još nije bio građanin Maribora. Građanstvo je stekao prije 1792, od koje se godine upisuje kao "građanski izrađivač orgulja«. Usp. J. A. Janisch, Topographisch-statistisches Lexikon von Steiermark, Graz 1885, I, str. 522.

40 NA, Protokol vizitacija arhidjakonata Bekšin, br. 85/XVI, str. 172.

41 Podaci iz podužeg zapisa u Spomenici župe Gornja Rijeka pod Kalnikom (tamošnji župski arhiv), iz kojega odnosni dio teksta glasi: (4.VIII 1818)»...ex hoc rescivi dictum organificem jam esse mortuum et praeter uxorem cum tribus sat teneris prolibus, praeterea $\mathrm{m} \mathrm{u} \mathrm{l} \mathrm{t} \mathrm{a} \mathrm{d} \mathrm{e} \mathrm{b} \mathrm{i} \mathrm{t} \mathrm{a} \mathrm{p} \mathrm{a} \mathrm{s} \mathrm{i} \mathrm{va} \mathrm{(podv.} \mathrm{L.} \mathrm{S.)} \mathrm{nullam} \mathrm{autem} \mathrm{substantiam} \mathrm{post} \mathrm{se} \mathrm{reliquisse,}$ imo jam plures parochos e diversis locis ad Magistratum Circuli recurisse, a quibus eodem titulo peccunias collegisset, sed in (-) cassum quoniam nulla adest substantia «.

42 Orgulje u Hrastovljanu (1796) nose br. 18, u Gornjoj Petrički (1800) br. 27, u Vel. Trojstvu (1802) br. 38. To znači da je između 1796. i 1800. izradio 9 orgulja ili oko 2 orgulje godišnje; između 1800. i 1802. čak 11 orgulja ili skoro 4 orgulje na godinu. Njegove najveće poznate orgulje u Hrvatskoj nisu sačuvane, a nalazile su se u crkvi u Ludbregu (1810, 15 reg.)

$42 \mathrm{a}$ H. Heilling, Barocke Orgelbaukunst in Steiermark. SINGENDE KIRCHE, Wien 1962, sv. 4. 


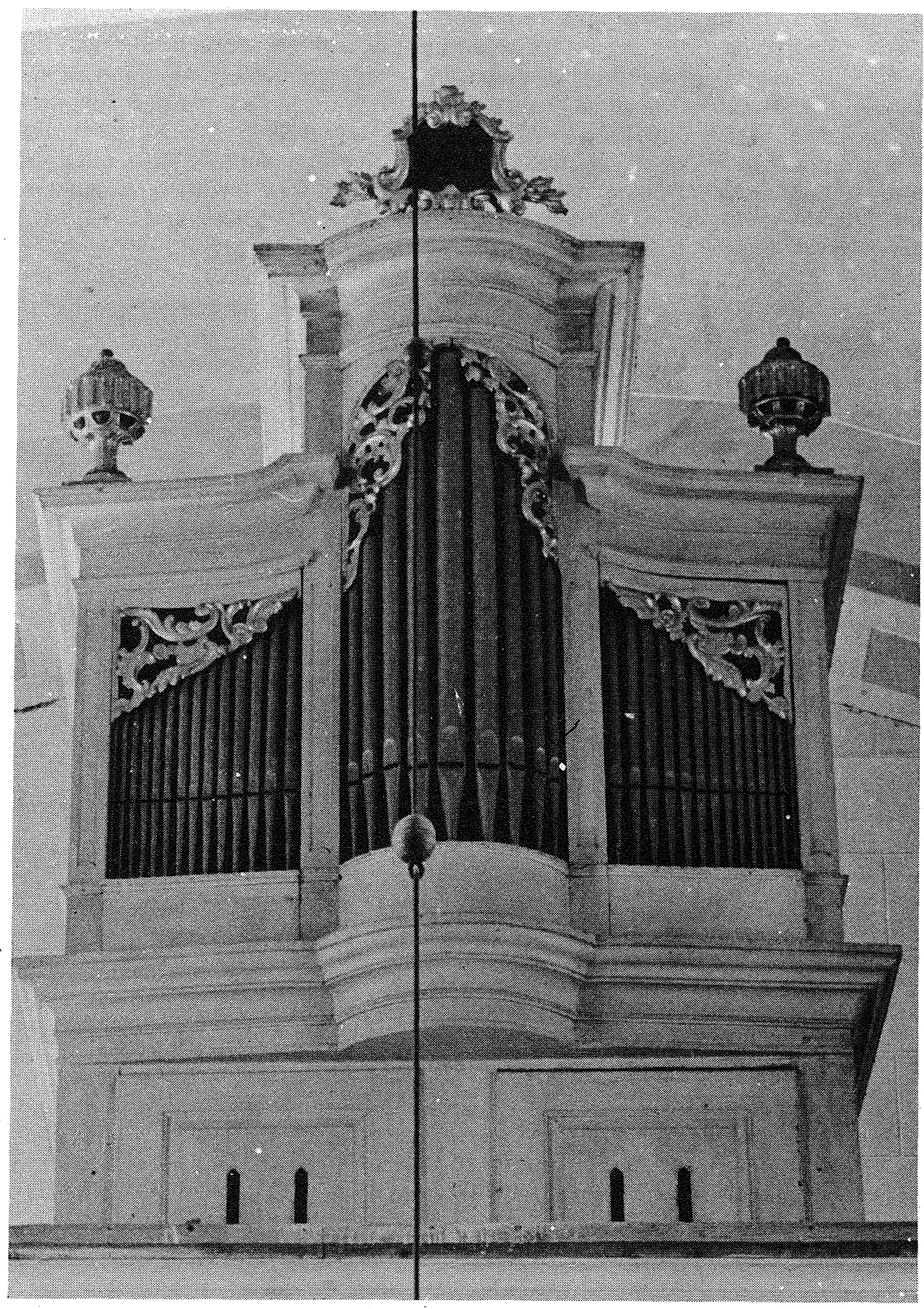

S1. 7 Hrastovljan (J. Otonič, 1796) 
registri jako stapaju s temeljnom Copulom 8 manuala. U manualu orgulja do 10 registara ne grade Principal 8 nego samo Copulu, koja je većinom preslaba. Po tome se ne razlikuju od ostalih naših graditelja toga vremena. Zvuk njihovih instrumenata, koliko se može zaključiti zbog većinom slaba stanja, nije dovoljno uravnotežen, pleno nije nosiv ni bogat. Kod orgulja u Trojstvu Josip pokušava učvrstiti temeljne 8-stopne registre dodavanjem otvorene Flaute 8 , što u nekoliko pomaže boljem zvuku plena. On također eksperimentira s dokidanjem pedalne klavijature bilo da pedalni 8-stopni registar naprosto prebaci u manual (G. Petrička), ili da pedalnu klavijaturu »smjesti« u tobožnji drugi manual (Hrastovljan, sl.

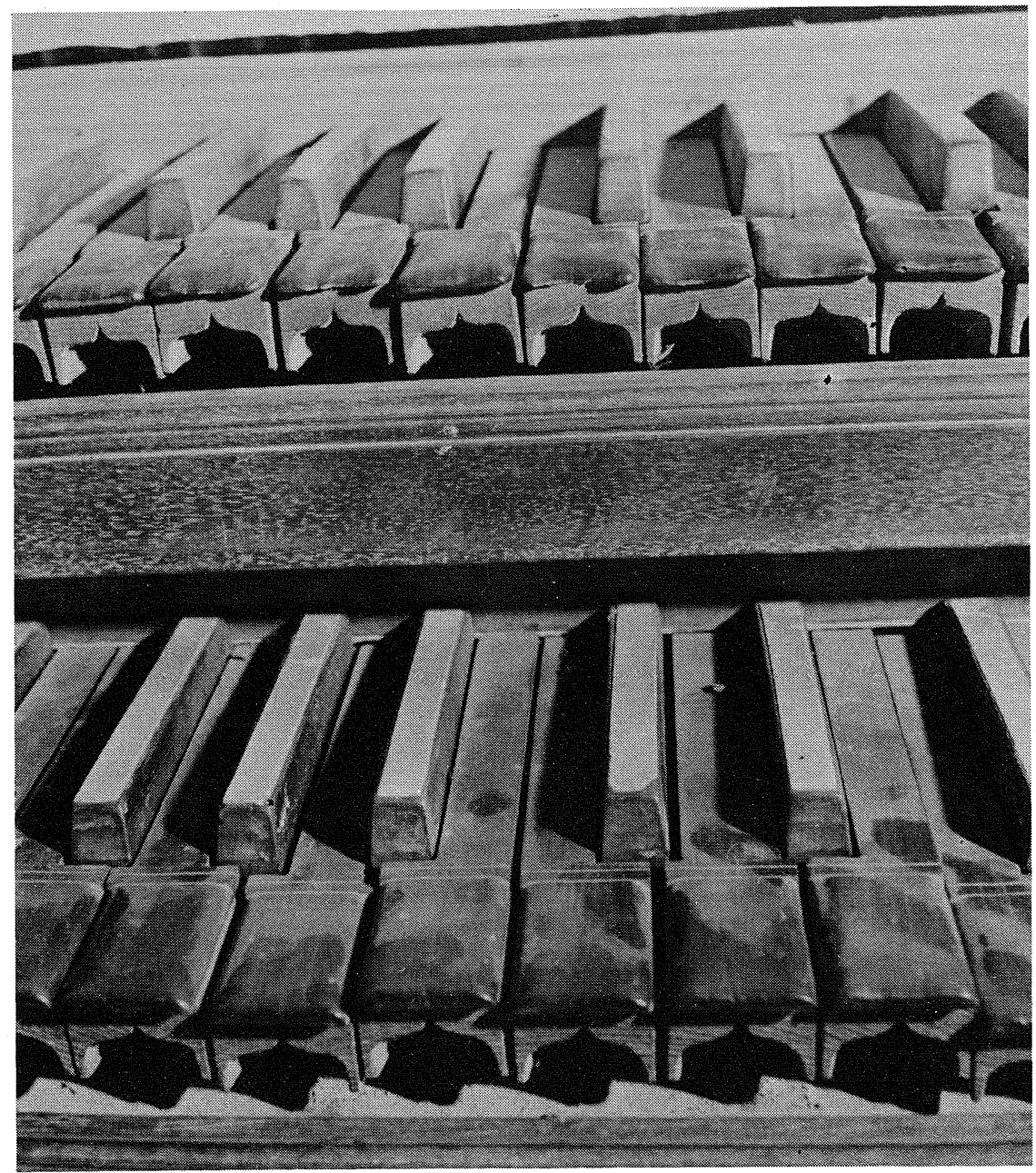

SI. 8 Hrastovljan, detalj sviraonika 
7 i 8), koji to ustvari nije. To su sigurno pokušaji da se skromnim seoskim orguljašima olakša sviranje orgulja.

Slijedeći graditelj iz Maribora je LEONHAR'T EBNER, poštovanja vrijedan i neobično solidan majstor, za kojega je velika šteta da se o njegovoj biografiji ništa ne zna. Djela mu susrećemo između 1860. i 1870., nakon koje mu se godine opet gubi trag. Način kojim gradi odaje čistu njemačku školu razdoblja romantizma, sazdanu na Töpferovim principima. Bio je vrstan majstor pa mu djela još uvijek vrlo dobro služe. Uvijek je pažljivo izrađivao orgulje, birao vrlo kvalitetan materijal i u svemu pokazao da je imao sigurno iskustvo. Posebno treba istaknuti vrlo lijepo rezbarena kućišta njegovih orgulja u dobrom neogotičkom stilu (sl. 9).

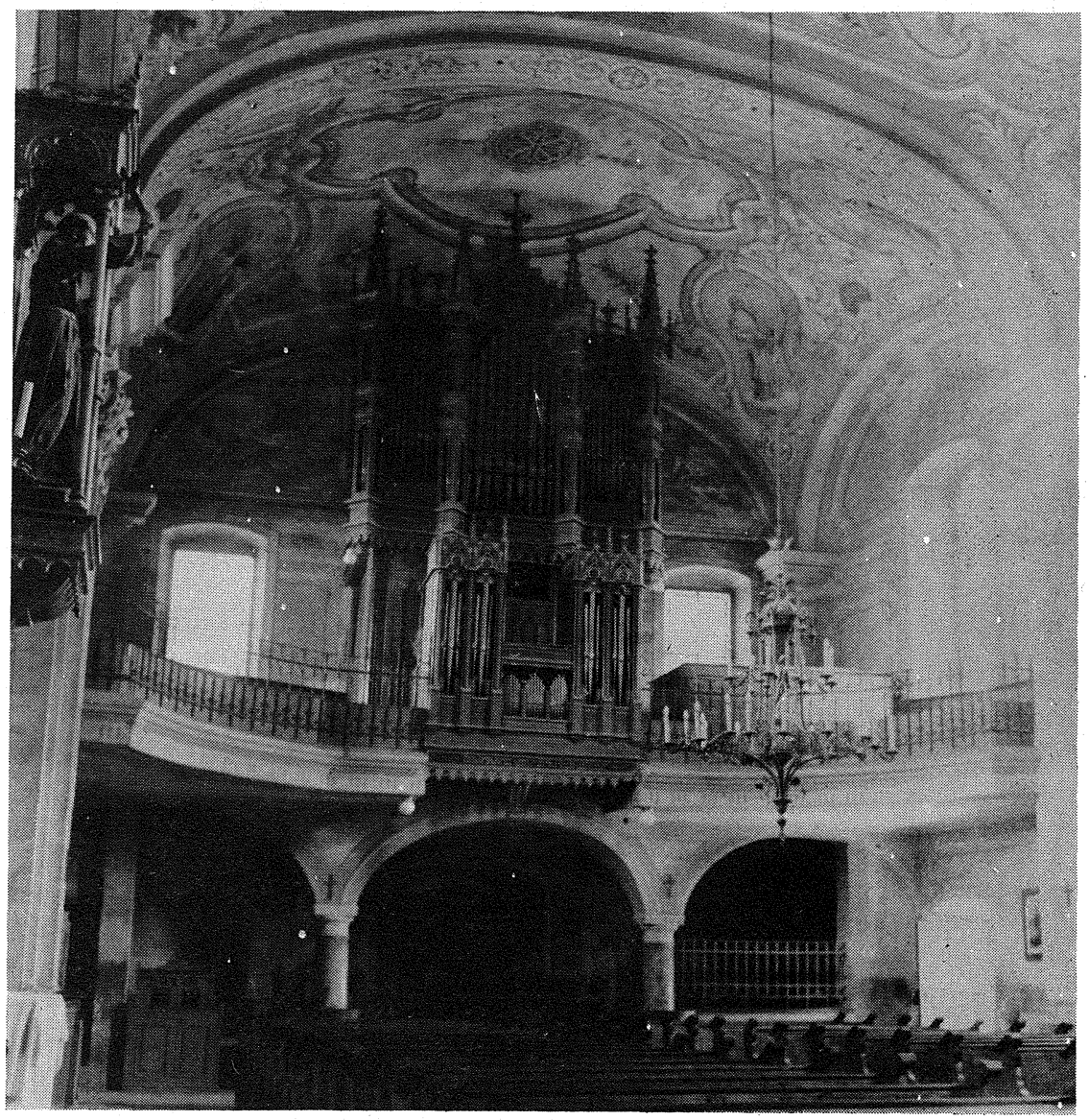

Sl. 9 Marija na Muri (L. Ebner, 1870) 


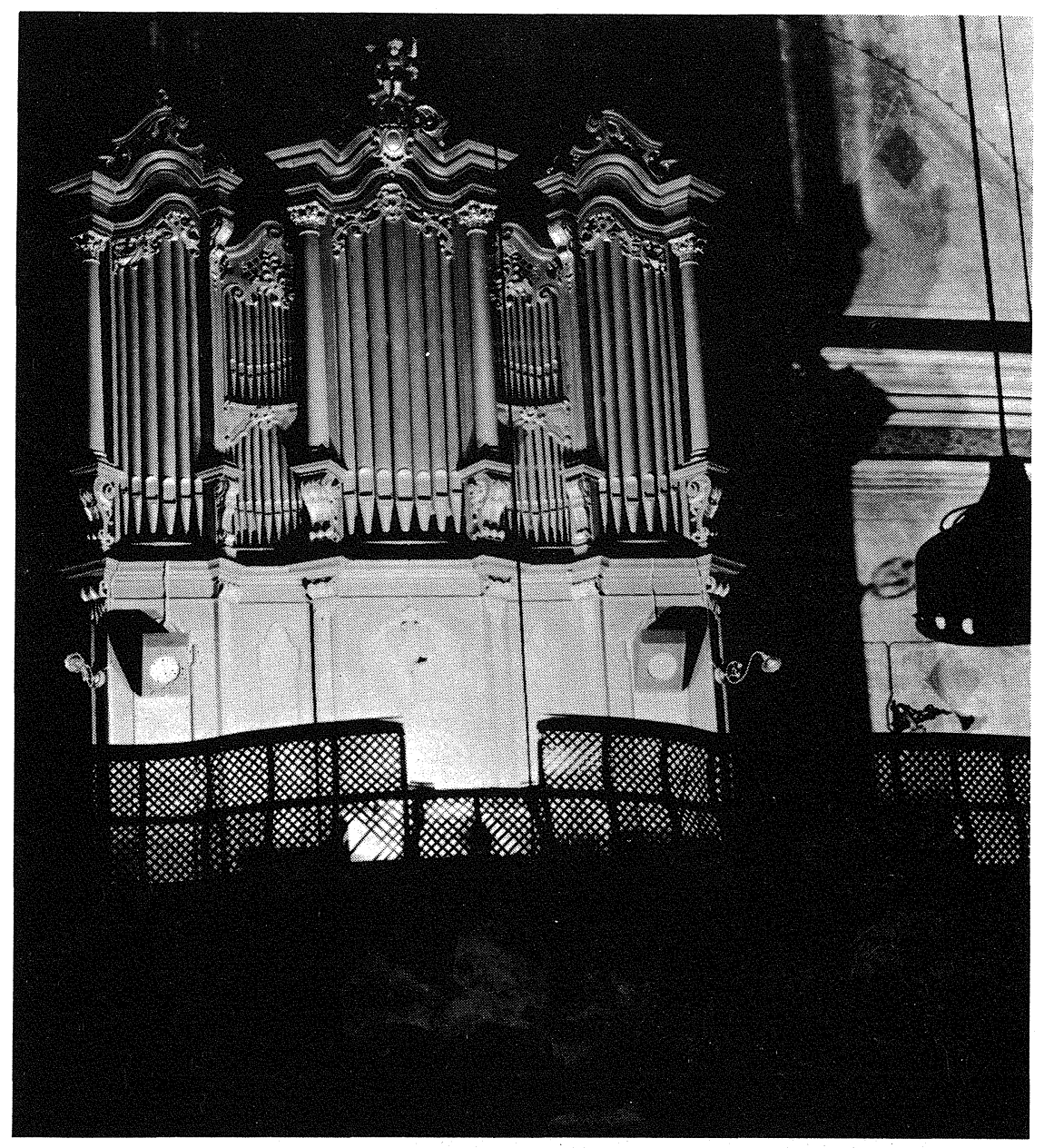

Sl. 10 Varaždin, župna crkva (J. Brandl, 1895)

MIJO KRAINC kao graditelj ne znači više od čiste prosjećnosti. Djela su mu dosta solidna iako posve bezlična. Možda je bio sin Matije Krainza iz Graza $(+1830) .43$

Posljednji mariborski graditelj ujedno je bio i najznačajniji. JOSIP BRANDL (1\$6744-1938), porijeklom iz Bavarske, gdje je izučio orguljarstvo, spada među

43 Federhofer, o.c., str. 47. - Janisch, o.c., spomınje jedne Mijine orgulje u Hajdini kod Ptùja (I, str. 517).

44 Podaci o Brandlovu rođenju ne podudaraju se: po jednima je rođen u Rosenheimu u Bavàrsköj 14. XI 1867 (Steırmärkisches Musiklexikon; str. 52), po drugima u Eisendorfu kod Münchena 1865 (nekrolog .u SV. CECILIJI 1938, str. 125). 
poslovno najuspešnije slovenske orguljare, čijih 52 instrumenta još uvijek postoje u Hrvatskoj (svi podaci u RZZSK). Izgleda da je svega izgradio oko 150 orgulja.

Poput Milavca i Brandl gradi orgulje s pneumatskim sustavom, vrlo solidno i zvukovno ugodno, zbog čega su se njegovi instrumenti sviđali i tražili. Gradio je za sve pokrajine Hrvatske, od sjevera do juga, pa i u Srijemu i Bosni, a ima više orgulja i u susjednoj Austriji. Njegove je radove vrlo cijenio poznati naš stručnjak i organista prof. Franjo Dugan (1874-1948), kako svjedoče mnogi njegovi prikazi u SV. CECILIJI. Brandl je 1904. postigao na izložbi u Napulju »Grand Prix«, ako smijemo vjerovati jednoj novinskoj vijesti. ${ }^{45}$ U Hrvatskoj su mu najveća i najpoznatija djela orgulje u župnoj (1895, 20 reg., sl. 10) i pavlinskoj (1933, 28 reg.) crkvi u Varaždinu, u Cavtatu i u katedrali u Dubrovniku (1937, 30 reg.).

\section{SAMOSTALNI ORGULJARI}

PETER RUMPEL (1787-1861) može se smatrati posljednjim izdankom barokne tradicije u najboljem smislu, na prijelazu u romantizam. Zato se oba pravca zrcale u njegovim djelima.

Rođen je i umro u Kamniku, gdje je imao posjed, kuću i veliku radionicu, ${ }^{46} \mathrm{koju}$ je uredio - prema vlastitim riječima - poput nekog tvorničkog pogona. ${ }^{47}$ Kako se nalazio u sredini gdje mu je nadohvat ruku bila za produkciju sva potrebna sirovina, dakako zato i niža po cijeni, bio je u stanju izrađivati vrlo kvalitetne instrumente a ipak jeftinije od ostalih konkurenata po gradovima. ${ }^{48}$ Osim za crkve po Sloveniji gradio je za Hrvatsku i Istru kao i za susjednu Korušku. Najkasnije oko 1855 , po izričitoj želji naručilaca i on je počeo graditi prema Töpferu. ${ }^{49}$

U Hrvatskoj su poznata samo 4 njegova djela, od kojih su najbolje očuvane (iako ponešto prerađene) orgulje u crkvi sv. Katarine u Zagrebu (1830), koje su odmijenile ranije djelo Ivana Fallera, koje se tu nalazilo. Po tim se orguljama vidi da je Rumpel bio zaista vješt i vrstan stručnjak, čiji bi rad trebalo pažljivo proučiti $\mathrm{i}$ istražiti.

Od manjih provincijskih samostalnih graditelja samo se s jednim djelom susreće ANDRO GÓSTL (1805-1885), čije su orgulje postojale (a možda postoje kao prerađene) u crkvi u Žakanju (1858).

JANEZ MANDLIN (1818-1885) zastupljen je s dvjema orguljama: $u$ Čabru (1864, o tim je orguljama kao upitnom njegovom djelu već bilo govora) i Kuniću Ribničkom na Kupi (1867). U potonjim orguljama postoje dvije zanimljivosti: u stolarski krasno izvedenom sviraoniku postoji ugrađena fisharmonika (harmonij), koja se uključuje posebnom malom polugom ispod manuala uz istovremeno isključenje orgulja, dok se zrak dobiva iz glavnog mijeha, a zatim vrlo originalna kon-

45 ZAGR. KATOLIĆKI LIST, Zagreb 1905, str. 26 (prikaz Brandlovih orgulja u Škenderovcima u Slavoniji).

46 Podaci o radionici prema novinskom oglasu u INTELLIGENZBLATT ZUR AGRAMER ZEITSCHRIFT br. 32 od 26. IV 1828.

47 Arhiv Hrvatske, spisi Ugarskog namjesničkog vijeća, Acta litterario-politica 1779-1849, konvolut spisa o orguljama akademske crkve sv. Katarine, sign. 1109/1830.

48 Ibidem.

49 Eberstaller, o.c., str. 134 - 135. - Samostan St. Paul in Lavanttal u Austriji posjeduje vrijedne Rumpelove orgulje na kojima se i danas vrše koncertne izvedbe i radio-prijenosi. 
strukcija za pogon mjehova u obliku skela, gdje se $\mathrm{n}$ ji h a $\mathrm{nj}$ e m omogućuje lako pokretanje mjehova, što je možda njegov vlastiti izum i zaslužio bi da se bar u crtežu sačuva. ${ }^{.0}$

ANDREJ RAČIČ (1803-1883) bio je posve prosječan zanatnik iz Cirkla kraj Krškog (gradio orgulje u Petrovini, 1858). Posve ispodprosječan graditelj bio je Matevž Sašek.(1837-1906), koji je po selima gornjeg Pokuplja ostavio troje orgulje. O njegovu se radu nema šta preporučljiva kazati. Svi ti orguljari gradili su isključivo po starom mehaničkom sustavu.

Novom vremenu pripadaju ANTON DERNIĆ, braća ZUPAN i ANTON PER̆INA, koji grade isključivo po pneumatskom sustavu. Naročito su se istakla braća IGNAC (1853-1915) i IVAN (1857-1900) ZUPAN iz Kamne Gorice, od kojih se prvi usavršavao u radionicama poznate češke tvrtke braće Rieger u Krnovu (Jägerndorf). Zupanovi su od Riegera preuzeli njihov način gradnje i sastava orgulja i uspješno ga primjenjivali na produkte vlastite tvrtke. U Hrvatskoj postoji njihovih 15 orgulja.

Posljednji slovenski graditelji ove skupine bili su JURIJ BENCZ (19)9-1945) iz Gorice (Gorizia), rođen u Mariboru, 5 ! čije samo jedne orgulje znamo u Hrvatskoj. Na žalost on je poznatiji po posve stilski promašenim preinakama brojnih vrijednih starih majstorskih orgulja u Istri, koje je naprosto upropastio, čime je nanio golemu kulturnu štetu. Drugi graditelj koga još treba spomenuti, doslovce zadnji, je ANDREJ BENDA iz Loke kod Mengeša, koji je zajedno s Jenkom radio na orguljama katedrale u Đakovu (1936), 52 a samostalno je radio orgulje za katedralu u Senju (1957).

\section{ZAKLJUČAK}

Svrha ovog skraćenog pregleda djelatnosti slovenskih graditelja orgulja $\mathbf{u}$ Hrvatskoj bila je da se pokaže kako su znatan udio u stvaranju crkvenog instrumentarija imali slovenski orguljari u 17. i 18. stoljeću, dok su još radionice u $\mathbf{H r}-$ vatskoj u zametku i vrlo neredovita pojava, kako zatim ta djelatnost u 19. stoljeću naglo opada i gubi na terenu, da bi se tek krajem istog stoljeća, a naročito u ovom stoljeću ponovo naglo podigla i zauzela istaknuto mjesto među dobavljačima orgulja iz ostalih zemalja.

Kolik je taj udio kazuju slijedeći podaci, dobiveni 1975. god. nakon dovršene evidencije orgulja kao spomenika kulture na čitavom teritoriju SR Hrvatske: u svemu je popisano 762 orgulja, od kojih samo na hrvatske radionice otpada 295 orgulja, na slovenske 153 , talijanske 81 , češke 81 , madžarske 46 i austro-njemačke 38 , dok je 71 orgulja ostalo za sada neidentificirano. Nema sumnje da će se među tima također naći još poneko djelo slovenskih graditelja.

Iznesene brojke pokazuju da sačuvani instrumenti slovenskih graditelja sačinjavaju oko j e d n u p e t i n u svih postojećih orgulja u Hrvatskoj, te da stoje na p r v o m mjestu ispred graditelja svih ostalih narodnosti.

50 Fotodokumentacija i zap. evid. br. 16 od 9. VII 1974. u RZZSK.

51 Radole, o.c., str. 130.

52 Pašićek, Slovenski Michelangelo svira, Reportaža u RTV-tjedniku »STUDIO« br. 616, Zagreb, 24. I 1976. 
Tih 153 orgulja gradilo je 27 graditelja. U popisu na kraju ovog rada, međutim, spomenuti su i svi ostali orguljarski zanatnici ili pomoćnici (daljih 16 imena), koji doduše nisu samostalno izradili niti jedne jedine orgulje, ali su na njima radili i popravljali ih, što sve zajedno znači da je na terenu Hrvatske radilo najmanje 43 slovenskih orguljara.

U popisu su navedene (ali nisu iskazane u broju od 153 orgulja) i orgulje za koje se samo zna iz arhivskih vrela ili štampe; stavljene su u zagrade, kako bi ipak pregled slovenskih majstora i njihovih djela bio što potpuniji.

Pošto su u gornjoj Hrvatskoj, dakle u Sloveniji najbližim hrvatskim pokrajinama, arhivski podaci za $\mathrm{v}$ e l i k i broj orgulja 18. stoljeća potpuno šturi i bez ikakva navoda imena graditelja ili provenijencije instrumenta, pored graditelja iz nekih austrijskih centara (Beč, Graz, Bruck a.M., Radkersburg), biti će u okvirima tog broja djelatan i velik broj upravo slovenskih graditelja, posebno iz celjskog $\mathrm{i}$ mariborskog okružja, čiji instrumenti doduše fizički više ne postoje $i$ teško da ćemo ikad saznati čiji su bili. Taj dio pregleda nužno ostaje nedorečen.

Sukcesivno i po međunarodno utvrđenim suvremenim stručnim normama provedeno restauriranje starih vrijednih orgulja, koje se od nedavna u Hrvatskoj uspješno provodi, dalo je iznenađujuće rezultate. Stari, već skoro posve napušteni instrumenti oživjeli su poslije restauriranja u novom sjaju, kao umjetnička glazbala postali su neobično zanimljivi za koncertno izvođenje stare orguljske glazbe, pa je već izdan čitav niz takvih ploča. Otkriveno je novo bogatstvo visokih umjetničkih vrednota iz kulturne baštine naših naroda, baštine koja još uvijek svojim najvećim dijelom čeka da bude otkrivena i revitalizirana.

Unutar fonda orgulja sjeverne Hrvatske zauzima niz djela starih slovenskih majstora značajno mjesto pa je za očekivati da će ovaj rad bar donekle pridonijeti cjelovitijem sagledavanju ove važne glazbeno-zanatske djelatnosti, koja još uvijek čeka na dolično vrednovanje unutar jugoistočnog evropskog orguljarstva.

\section{POPIS IMENA GRADITELJA I NJIHOVIH ORGULJA}

BENCZ JURIJ-GIORGIO - 1 orgulje

Novigrad (Istra), op. 38 (1937), 8 reg.

BENDA ANDREJ - 1 orgulje

Senj, katedrala (1957), 16 reg.

BRANDL JOSIP - 52 orgulje

Krapina, franjevci, (pr. 1895), 10 reg.

Varaždin, ž. crkva, (1895), 20 reg.

Staro Petrovo Selo, (1901), 8 reg.

Ljubeščica, (1901), 6 reg.

Vukovina, op. 38 (1906), 13 reg.

Škenderovci, op. 40 (1905), 6 reg.

Čakovec, franjevci, op. 43 (1906), 19 reg.

Draškovec, op. 45, 9 reg.

Čadavica, op. 50 (1906), 10 reg.

Kaptol u Slavoniji, op. 52 (1906), 8 reg.

Vinagora, op. 53, 8 reg.

Sunja, op. 55, 12 reg. 
Šarengrad, franj., op. 55, 9 reg.

Slav. Požega, ž. crkva, (oko 1906), 13 reg.

Ilača, op. 59 (1907), 6 reg.

Desinić, op. 60, 16 reg.

Oborovo, op. 62 (1908), $16 \mathrm{reg}$.

Donja Zelina, op. 64 (1908), 8 reg.

Ozalj, op. 65, 8 reg.

Gornja Rijeka, op. 66 (1908), 10 reg.

Juraj $u$ Trnju, op. 76, 10 reg.

Vukovar, kapela dvorca, op. 77, 6 reg.

Vidovec kr. Varaždina, op. 88, 9 reg.

Podturen, op. 88(!), 9 reg.

Nova Kapela, op. 88(!), 10 reg.

Štrigova, ž. crkva, op. 89 (1910), 10 reg.

Mala Solina, op. 91 (1911), 6 reg.

Sisak, ž. crkva, (1911), $17 \mathrm{reg}$.

Sisak-Predgrađe, [1912], 6 reg.

Sinac, op. 92 (1912), 8 reg.

Jastrebarsko, franj. samostan, (1912), 7 reg.

Trg kraj Ozlja, op. 96, 4 reg.

Gojlo, op. 97 (1912), 4 reg. (sada Podsused)

Veliki Bisag, op. 102 (1913), 7 reg.

Margečan, op. 103 (1913), 7 reg.

Peščenica, op. 106 (1913), 7 reg.

Domagovic, op. 108 (1913), 7 reg.

Selnica, op. 111, 9 reg.

Remetinec kr. Varaždina, op. 112 (1913), 10 reg.

Molve, (1914), 19 reg.

Posavski Bregi, op. 117 (1915), 15 reg.

Koprivnički Ivanec, 9 reg.

Lopatinec, op. 122 (1923), 17 reg.

Pakrački Gaj, op. 123 (1923), 10 reg.

Zagreb, Muzička akademija, (1927), 14 reg., sada u Odri

Split, konventualci sv. Frano, (1931), 14 reg.

Vranjic, (1931), 8 reg.

Varaždin, pavl. crkva, op. 140 (1933), 28 reg.

Cvetlin, (1936), 11 reg.

Split, dominikanci, (1936), 13 reg.

Dubrovnik, katedrala, op. 144 (1937), 30 reg.

Cavtat. op. 149 (1938), 16 reg.

DERNIČ ANTON - 2 orgulje

Trviž, (1911), 16 reg.

Sv. Vid, na Krku, op. 7 (1913), 6 reg.

DEV FRANC KSAVER - 1 orgulje

Gerovo, (1856), 12 reg.

EBNER LEONHART -2 orgulje

Krapinske Toplice, (1860), 17 reg.

Marija na Muri, (1870), 16 reg. 
EISL IVAN JURAJ - 4 orgulje

Marija Gorica, (1759), 14. reg.

Donja Kupčina, (1759), 7 reg.

Svetice, (1761), 9 reg.

Sv. Petar u Šmi, (oko 1770), 10 reg.

FALLER IVAN - 2 orgulje

[Zagreb, sv. Katarina, (1688-9), 15. reg.]

[Zagreb, katedrala (1689-90), 19 reg.]

Frankovič Jožef

GORŠIČ FRAN - 1 orgulje

Prezid, op. 42,-(1855), 13 reg.

GÖSTL ANDRO - 1 orgulje

Žakanje, (1858), 10 reg.

Hall Ivan

Hall Zefrin

JANEČEK IVAN FRANJO - 5 (8) orgulja

[Zagreb, katedrala, (1726), pozitiv]

Laduč, (1733),6 reg., pozitiv

[Zagreb, sv. Marko, (1740-41), 22 reg.]

Kupinec, (1752), 6 reg., pozitiv

[Sisak, ž. crkva, (1767), 6 reg., pozitiv]

Olimje, (1764), 14 reg.

Brezovica, (177.1), 6 reg., pozitiv

Sela kraj Siska, (1777), 11 reg.

JENKO FRANC - 25 orgulja

Kostrena, (1930), 9 reg.

Rijeka, Srce Isusovo, (1931), 15 reg.

Đakovo, katedrala, op. 22 (1936), 73 reg.

Draž, op. 35 (1939), 12 reg.

Rijeka-Trsat, B.D. Marija, (1940); 26 reg.

Dubrovnik, ss. Srca Isusova, op. 41 (1940), 16 reg.

Primošten, op. 48 (1941), 14 reg.

Osijek, Donji grad, (1950), 24 reg.

Rijeka, kapucini, op. 67 (1953), 29 reg.

Zagreb, M.B. Lurdska, op. 75 (1955), 18 reg.

Sinj, B.D. Marija, op. 81 (1958), 29 reg.

Šibenik-Varoš, B.D. Marija, op. 83 (1958), 17 reg.

Vodice, op. 91 (1960), 12 reg.

Pula, sv. Ante, op. 95 (1961), 18 reg.

Zagreb, Ranjeni Isus, op. 101 (1963), 13 reg.

Metković, op. 103 (1963), 20 reg.

Sumartin, op. 104 (1964), 14 reg.

Rijeka, sv. Terezija, op. 109 (1965), 16 reg. 
Jalžabet, op. 108 (1965), 10 reg.

Split, kapucini, op. 112 (1966), 17 reg.

Sibenik, katedrala, op. 119 (1968); $27 \mathrm{reg}$.

Opuzen, op. 121, (1969), 10 reg.

Rijeka, katedrala, op. 124 (1969), 18 reg.

Svibovec, op. 129 (1970), 10 reg.

Makarska, ž. crkva, op. 128 (1970), 10 reg.

Koritnik Franc

KRAINC MIJO - 3 orgulje

Donji Kraljevec, (1877), 8 reg.

Kuzminec, (1877), 12 reg.

Mala Subotica, (oko 1873), 12 reg.

KUČERA JOSIP ALOJZ - 1 orgulje

Lipnik, op. 10 (1785), 8 reg.

MALACHOVSKY ANDREJ FERDINAND - 5 orgulja Novo Selo Okićko, (1859), 10 reg.

Plešce, (1860), 10 reg.

Plešivica, ž. crkva, (1864), 12 reg.

Bukevje, (oko 1865), 12 reg.

Praputnjak, (1870), 13 reg.

MANDLIN JANEZ - 2 orgulje

Cabar, (1864), 12 reg.

Kunić Ribnički, (1867), 8 reg.

Marchisetti Blaž

Marchisetti Jožef

Marchisetti Vinko

Mašek Ignac

Mašek Jožef

Matija iz Maribora

MILAVEC IVAN - 3 orgulje Košljun, op. 10 (1908), 10 reg. Punat, op. 19 (1912), 11 reg.

Karlovac, franjevci, op. 36 (1914), 19 reg.

OTONIČ JOSIP - 4 (7) orgulja

Hrastovljan, op. 18 (1796), 10 reg.

[Koprivnički Bregi, (1798), 6 reg.]

Gornja Petrička, op. 27 (1800), 8 reg.

Veliko Trojstvo, op. 38 (1802), 11 reg.

Močila, (oko 1807), 8 reg.

[Ludbeg, (1810), 15 reg.]

[Śtrigova, sv. Jeronim] 
OTONIČ SIMON - 5 orgulja

Zelendvor, (oko 1765), 6 reg.

Sopot, (1766), 6 reg., pozitiv

Radovan, (1774), 8 reg., pozitiv

Petrijanec, (1777), 8 reg.

Hraščina, (1779), 9 reg.

PER̃INA ANTON - 9 orgulja

Donji Vidovec, (1933), 12 reg.

Slavonski Brod, ž. crkva, (1936), 12 reg.

Ferdinandovac, (1936), 11 reg.

Ždala, (1939), 11 reg.

Pokupsko, (1939), 11 reg.

Križišce, (1940), $10 \mathrm{reg}$.

Cerna, (1940), 10 reg.

Komletinci, (1946), 10 reg.

Levanjska Varoš, oko 10 reg.

Prašnik Jakob A.

RAČIČ RUDOLF - 1 orgulje

Petrovina, (1858), 8 reg.

Rebolj Vinko

RUMPEL PETER - 3 (4) orgulja Zagreb, sv. Katarina, (1830), 12 reg.

Mošćenice, (1847), 12 reg.

Grobnik, (1848)

[Trsat, B.D. Marija, (1850)]

SCHOLZ ANTON - 8 orgulja

Dol Pribićki, (1782), 6 reg., pozitiv

Poljanica Bistranska (1784), 6 reg., poz.

Gornja Bistra, dvorac, (oko 1784), 5 reg.

Volavje, (1785), 6 reg., pozitiv

Gotalovec, (1787), 4 reg., pozitiv

Novaki, (1794) 3 reg., pozitiv

Kostajnica, franjevci, (1797), 14 reg.

Nedjelja, (1799), 7 reg., pozitiv

Schilhan Anton

ŠAŠEK MATEVŽ - 3 orgulje

Reštovo, (1880), 8 reg.

Mišinci, (1884), 6 reg.

Bubnjarci, (1885), 12 reg. 
Turk A.

Waibl Robert

WALLENSTEIN ANDRIJA SEBASTIJAN - 1 orgulje [Zagreb, franjevci, (1708-9), 12. reg.]

Wester Franjo

ZUPAN, braća (IGNAC ml. i IVAN) -15 orgulja

Rijeka, salezijanci, op. 32, 6 reg., sada Gornje Jesenje

Omišalj, op. 85 (1895), 8 reg.

Drniš, op. 65, 16 reg.

Opatija, op.76 (1900), 7 reg.

Čepić, op. 85 (1902), 9 reg.

Lovran, op. 92 (1903), 9 reg.

Gračišće, op. 97 (1906), 10 reg.

Žminj, op. 37 (!), (1906), 12 reg.

Dobrinj, op. 101 (1907), 9 reg.

Bogovići, op. 104 (1907), 8 reg.

Roč, op. 105 (1907), 11 reg.

Šibenik, sv. Ivan, op. 111 (1910), 11 reg.

Volosko, op. 119 (1910), 13 reg.

Kringa, op. 122 (1912), 14 reg.

Lindar, op. 15(!), (1913), 8 reg.

\section{Fotografije:}

dr Doris Baričević: 3, 4, 5, 7

I. Keleminčić: 1,2

K. Klaić: 6

N. Vranić: $8,9,10$

\section{SUMMARY}

Although organist Matthew, who repaired the organ of the Zagreb Cathedral, is mentioned in the Maribor archives already in 1501 and 1502, true contacts between Slovenia and Croatia were established only towards the end of the 17th century. Ever since, for nearly three hundred years, organs for Croatia have been ordered from mostly three Slovene building centres: Ljubljana (from 1688 up to today), Celje (only during the 18th century) and Maribor (from the latter half of the 18th century up to 1938).

Apart from these centres, throughout the 19th century, there is a number of independent builders in smaller towns; however, their workshops were: the enterprize of one person or family only, lasting for a rather short period of time and usually terminated when the master died.

Historically, older Slovene organ builders mostly transplanted building knowledge from various foreign centres. Thus, the organ builders of the 17th/18th century Ljubljana circle import influences from Southern Germany (I. Faller) or Salzburg (I. J. Eisl), those from Celje influences of the Czech school (I.F. Janeček, A. Scholz), whereas the Maribor builders bring in characteristics of the Styrian circle in Graz (S. + J. Otonič).

In the 19th century, in the romantic period, the transition to which is represented by $P$. Rumpel from Kamnik, the Ljubljana circle takes the lead (A. F. Malachovsky, F. Goršič, F. 
Ks. Dev), followed by L. Ebner in Maribor, whereas in the 20th century, I. Milavec in Ljubljana, brothers Zupan in Kamna Gorica and J. Brandl in Maribor become the main representatives of modern organ building. This line finishes with F. Jenko.

According to the organ inventory made in 1975 there exist in Croatia 153 organs built by Slovene masters from 1759 up to the present; of the number mentioned, 24 organs belong to the 18 th, 24 to the early 19th century, whereas 106 organs were made since 1890 .

The article reveals 27 names of masters from Slovenia whose works have survived in Croatia; together with 16 names of other assistants there are altogether 43 organ builders that have been active in Croatia. In the appendix the catalogue gives the general data about the place and disposition of organs, whereas organs mentioned in brackets either do not exist any more or are known of only from archivic sources or press.

Of the 762 organs registered in Croatia, one fifth originates from Slovene masters who represent the most numerous group of organ builders of non-Croat nationality. The aim of the article is to offer a kind of inventory of work done by Slovene builders in Croatia and thus to contribute to the history of building organs in Slovenia. 